\title{
Cattleya forbesii x Cattleya bowringiana: a new hybrid of Cattleya orchid
}

\section{Ronan Carlos Colombo ${ }^{1}$, Rodrigo Thibes Hoshino ${ }^{1}$, Edilene Aparecida Preti Ferrari ${ }^{1}$, Guilherme Augusto Cito Alves ${ }^{1}$ and Ricardo Tadeu de Faria ${ }^{1^{*}}$}

\begin{abstract}
The hybrid between Cattleya forbesii x Cattleya bowringiana shows flowers of lilac coloration, labellum with a light yellow center and striated with purple stripes of the same tone of other floral whorls. The plant flourished four years after seeding and produced, on average, six flowers.
\end{abstract}

Key words: Plant breeding, orchid, selection.

\section{INTRODUCTION}

The cultivation of species of the Orchidaceae family and its hybrids has increased in the last decades, representing around $8 \%$ of the ornamental plants global market (Chugh et al. 2009). In the Brazilian floriculture (flower farming), the cultivation of flowers and potted plants have gained prominence in the emerging markets of orchids, bromeliads among others (Junqueira and Peetz 2014). Thus, considering the great genetic diversity of native species in Brazil, one strategy to leverage the national sector and make it self-sufficient is to establish Brazilian plant breeding programs for flowers and ornamental plants (Cardoso 2013); which makes it possible to obtain hybrids that are more adapted to our climatic conditions (Faria and Colombo 2015) and reduces the dependence on importation of Asiatic hybrids.

However, there have been few studies on breeding orchids due to the long cycle of plants in the Dendrobium genus i. e., which leads to an average flowering development of three to four years (Vichiato et al. 2014). Faria et al. (2009), Faria et al. (2011), and Faria et al. (2013), working with Dendrobium crosses, were successful in obtaining three new cultivars (UEL 6, UEL 7 and UEL 8), which expressed the desired characteristics of mother plants such as flower size, flower coloration, flourishing period, number of flowers, plant height, among others. Faria et al. (2015) also obtained a hybrid of Oncidiuns which, besides presenting desirable agronomic characteristics for a hybrid, gave more balance and symmetry to the flowers, between the floral whorls.

However, from all the cultivated orchid genera, the Cattleyas and their hybrids are the most popular and more desired by consumers. Among the several species included in this genus, the Cattleya forbesii and $C$. bowringiana stands out for being present as parental in several commercial hybrids; but, there is no registration of a direct cross between these species.

The Cattleya forbesii Lindl. occurs mainly in the states of São Paulo, Paraná
Crop Breeding and Applied Biotechnology 17: 184-186, 2017 Brazilian Society of Plant Breeding. Printed in Brazil http://dx.doi.org/10.1590/1984$70332017 v 17 n 2 c 28$
*Corresponding author: E-mail: faria@uel.br

Received: 12 June 2015 Accepted: 26 April 2016

\footnotetext{
${ }^{1}$ Universidade Estadual de Londrina, Departamento de Agronomia, Rodovia Celso Garcia Cid, PR 445, km 380, Campus Universitário, CP 10.011, 86.057-970, Londrina, PR, Brazil,
} 
and Santa Catarina, and is a plant of medium height, with around $20 \mathrm{~cm}$ high, bifoliate, and predominantly epiphyte. Floral stems grow on top of fully developed pseudobulbs, giving origin to flowers (two to four, in general) of light brown to yellowish coloration and pink to golden yellow labellum. Inflorescence is long, with one to two unattractive flowers per stem, of good dimensions and durability (15-20 days), whose flourishing season occurs, in general, in the months of December and January. In general, the first flowering takes place when the plant reaches three years of age. They need relative humidity of 40 to $80 \%$, temperatures between 20 and $35{ }^{\circ} \mathrm{C}$ and luminosity of 50 to $60 \%$. They are normally grown in clay pots, since they do not adapt to long periods of humidity in the roots (Cardoso and Israel 2005).

The Cattleya bowringiana originates from Guatemala and Honduras. It is a more vigorous plant, bifoliate, around $60 \mathrm{~cm}$ high, with lilac flowers, $8 \mathrm{~cm}$ of diameter, and its first flowering occurs at five years of age. Flourishing season occurs in January/February.

The objective of this work was to describe the orchid hybrid originated for a cross between Cattleya forbesii $\mathrm{x}$ Cattleya bowringiana.

\section{BREEDING METHODS}

The hybrid was obtained from the Londrina State University (UEL) Agronomy Department orchid breeding program. Hybridization was done through controlled manual pollination, and pollinea from the donor plant (Cattleya bowringiana) were collected from recently-opened flowers (72 hours after anthesis) and transferred to the recently-opened flowers stigma ( 24 to 48 hours after anthesis) of the receiver plant (Cattleya forbesii).

The capsule containing the seeds matured at 10 months after crossing. Seeds germination occurred in vitro, in a MS (Murashige and Skoog 1962) culture medium, with half the concentration of macronutrients, with the addition of $1.0 \mathrm{~g} \mathrm{~L}^{-1}$ of activated coal, $30.0 \mathrm{~g} \mathrm{~L}^{-1}$ of saccharose and $7.0 \mathrm{~g} \mathrm{~L}^{-1}$ of agar. The $\mathrm{pH}$ was adjusted to 6.2 , and seedlings were sub-cultivated in the same culture medium.

Seedlings acclimatization took place after 12 months, in $25 \times 25$ styrofoam trays (collective vase), $5.5 \mathrm{~cm}$ high, using sphagnum (peat moss) as substrate. Seedlings were kept in an agricultural greenhouse for six months, covered with a transparent polyethylene film and black plastic screen (Sombrite ${ }^{\circ}$ ), a with luminous retention rate of $50 \%$.

Seedlings were then transplanted to black plastic vases with $6 \mathrm{~cm}$ of diameter and $8 \mathrm{~cm}$ high, where they remained for 12 months; being once again transplanted to black plastic vases of $17 \mathrm{~cm}$ of diameter and $15 \mathrm{~cm}$ high. The substrate used was Pinus bark and coconut fiber (Amafibra ${ }^{\circ}$, Holambra, Brazil) $(1: 1, \mathrm{v} / \mathrm{v})$. During these phases, the plants were fertilized with Biofert Plus ${ }^{\circ}$ (08-09-09), $5 \mathrm{~mL} \mathrm{~L}^{-1}$ of water, every 30 days.

For the morphological description of the hybrids, 10 plants were evaluated for their vegetative part phytometric characteristics: pseudobulb length and diameter, leaf length and width, and phytometric characteristics of their reproductive part: floral stem length, flower width and length and number and durability of the flowers (days).

\section{CHARACTERISTICS OF THE HYBRID}

Due to genic segregation, only 10 plants with similar characteristics were selected, which expressed the hybrid desired characteristics: flourishing precocity and greater number of flowers. The selected hybrid of Cattleya forbesii x Cattleya bowringiana is a plant with an average floral stem $16.5 \mathrm{~cm}$ long, pseudobulbs $26.9 \mathrm{~cm}$ long and $1 \mathrm{~cm}$ of diameter, similar characteristics of the Cattleya bowringiana. Obtuse, symmetric and oblanceolate leaves are, on average, $11.8 \mathrm{~cm}$ long and $4.3 \mathrm{~cm}$ wide (Table 1).

Table 1. Morphological descriptions of Cattleya forbesii, Cattleya bowringiana and of the resultant hybrid of this species cross. Pseudobulb length (PL), pseudobulb diameter (PD), leaf length (LL), leaf width (LW), floral stem length (FSL), flower width (FW), flower length (FL), flower number (FN) and durability of the flowers (DF)

\begin{tabular}{lccccccccc}
\hline Species & PL $(\mathrm{cm})$ & PD $(\mathrm{cm})$ & LL $(\mathrm{cm})$ & LW $(\mathrm{cm})$ & FSL $(\mathrm{cm})$ & FW $(\mathrm{cm})$ & FL $(\mathrm{cm})$ & FN & DF $($ days $)$ \\
\hline C. forbesii & 22.0 & 0.7 & 12.0 & 5.0 & 10.0 & 8.0 & 8.0 & 3 & $15-20$ \\
C.bowringiana & 26.7 & 1.4 & 12.8 & 4.3 & 17.2 & 8.0 & 9.0 & 10 & 15 \\
Hybrid & 26.9 & 1.0 & 11.8 & 4.3 & 16.5 & 6.9 & 6.9 & 6 \\
\hline
\end{tabular}


The hybrid showed precocious flowering, which occurred at 4 years of age, similar to what occurred with the female parental, an interesting fact from the commercial standpoint. Flowering took place in the month of December, with an average of 6 flowers per pseudobulb and showed and an average flower durability of 17 days.

The hybrid shows floral characteristics of $C$. forbesii, large labellum, pointing downwards and curved on the column, with a light yellow center and striated with purple stripes. Sepals and other petals showed lilac coloration, being the sepals widely open and smaller than the lateral petals (Figure 1 ).

\section{GERMPLASM MAINTENANCE AND SEEDLING DISTRIBUTION}

Plants resulting from the Cattleya forbesii x Cattleya bowringiana cross are micro-propagated and kept in the Universidade Estadual de Londrina, Agronomy Department greenhouse located at Rodovia Celso Garcia Cid, PR 445, km 380, Campus Universitário, CP 10.011, 86.057-970, Londrina, PR.

\section{ACKNOWLEDGEMENTS}

To CAPES for the financial support and Geraldo Lopes da Silva, the Universidade Estadual de Londrina technician from the orchid greenhouse.

\section{REFERENCES}

Cardoso JC and Israel M (2005) Levantamento de espécies da família Orchidaceae em Águas de Sta. Bárbara (SP) e seu cultivo. Horticultura Brasileira 23: 169-173.

Cardoso JC (2013) Melhoramento de espécies ornamentais como estratégia para o desenvolvimento e autossuficiência do setor. Horticultura Brasileira 31: 171-171.

Chugh S, Guha S and Rao I (2009) Micropropagation of orchids: A review on the potential of different explants. Scientia Horticulturae 122: 507-520.

Faria RT, Takahashi LSA and Lone AB (2009) UEL 6: nova cultivar de Dendrobium. Horticultura Brasileira 27: 114-115.

Faria RT, Takahashi LSA, Lone AB, Barbosa CM, Takahashi A and Silva GL (2011) UEL 7: nova cultivar de Dendrobium. Horticultura Brasileira 29: 441-442.

Faria RT, Takahashi LSA, Lone AB, Souza GRB, Silva GL and Hoshino RT (2013) UEL 8: nova cultivar de Dendrobium. Horticultura Brasileira
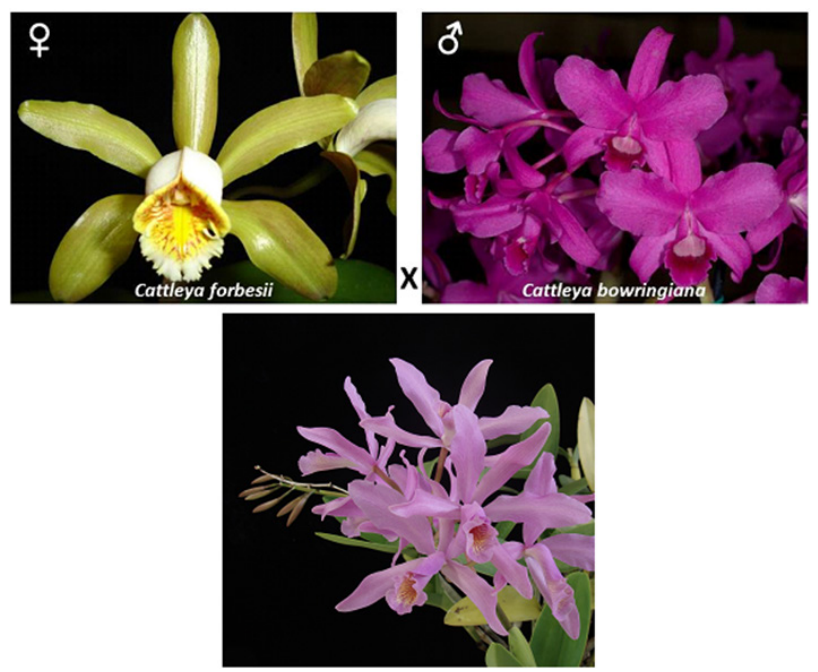

Figure 1. Flowers from parental genotypes and the Cattleya forbesii x Cattleya bowringiana hybrid.
31: 509-511.

Faria RT, Colombo RC and Hoshino RT (2015) Oncidium sarcodes x Oncidium Aloha '/wanaga': nova opção de híbrido de Oncidium. Horticultura Brasileira 33: 131-134.

Faria RT and Colombo RC (2015) Oncidium: a orquídea em expansão no cenário florícola. Horticultura Brasileira 33: 533.

Junqueira AH and Peetz MS (2014) O setor produtivo de flores e plantas ornamentais do Brasil, no período de 2008 a 2013: atualizações, balanços e perspectivas. Revista Brasileira de Horticultura Ornamental 20: 115-120.

Murashige T and Skoog F (1962) A revised medium for rapid growth and bioassays with tobacco tissue cultures. Physiologia Plantarum 15: 473-497.

Vichiato MRV, Vichiato M, Pasqual M, Rodrigues FA and Castro DM (2014) Morphological effects of induced polyploidy in Dendrobium nobile Lindl. (Orchidaceae). Crop Breeding and Applied Biotechnology 14: 154-159. 